\title{
E2F4 Gene
}

National Cancer Institute

\section{Source}

National Cancer Institute. E2F4 Gene. NCI Thesaurus. Code C125264.

This gene plays a role in tumor suppressor-dependent transcriptional regulation. 